C L Á U D I M A F R A

\section{TEMPO DE LEVITAR}

Juiz de Fora, 2000

Parecia a continuidade

de um sonho.

Mas o sol estava ali

no dia azul

só p’ra desmentir.

Estavam ali os objetos

do quarto,

os sons da casa,

o latido do cão .

Havia mesmo despertado.

Mas o corpo não:

mantinha a sensação

de flutuar

e uma alegria efervescente

e cintilante

dominava a alma.

E mesmo que uma ligeira nuvem

de tristeza,

pairasse nesse céu do quarto

(ao pensar no peso

das horas que viriam:

alegria e pânico

no mesmo palco, onde

vida e morte contracenariam)

mesmo assim,

era a alegria que

me vestia o corpo

quando ajeitei

o terno

e adentrei o dia.

\section{ANJO DA GUARDA}

Já não me comunico com este ser secreto e desmaterializado que vive em mim.

Ouço-lhe vez por outra apenas um alerta em tom de reclamação.

Quando escrevo um poema sinto que fica por perto curioso

(feito meu antigo anjo da guarda descesse daquele quadro);

e nesses momentos sinto saudade do tempo em que sentia os cheiros junto com a cor e nem dava pelo milagre!

Hoje nos vemos de vez em quando sempre que o alarido desses dias permitem:

apenas um roçar de lembranças como quem vive um rápido "déjavù". 


\section{P O E S I A}

\section{POEMA BRANCO}

Juiz de Fora, 28.06.06

Nosso lençol secando

branco na praia (do sol que viria)

Meu olhar inquieto propõe

agitado pelo vento

da manhã (que seria);

ainda o orvalho empalidece

a grama (na espera da viagem

pelo sol);

ainda brancas cintilâncias

anunciam a luz

no horizonte;

branca

a lua mergulha

num desmaio de brancura

e a praia começa

a se colorir

de branco.

à paisagem

os tons pastel

que ainda resistiam

à nuvem branca

que nos envolveu:

de repente nossa vida

apaga assim

no infinito de uma tela branca.

Diante de min

as investidas do vento

descolorem de vez

o momento

brincando irresponsavelmente

com a brancura agonizante

de nosso lençol.

Claudio Mafra é arquiteto mineiro bem conhecido, com projetos premiados na área de museus e de bibliotecas universitárias. Muito menos conhecida éa sua veia poética, cultivada discretamente, da qual a Ciência \& Cultura revela aqui três exemplos até agora inéditos. 